\title{
Evaluation of Different Calculation Procedures for Microhistological Analysis
}

\author{
JERRY L. HOLECHEK AND BRYAN D. GROSS
}

\begin{abstract}
This study evaluated 3 procedures for calculating dry weight composition of forage mixtures when microhistological analysis was used. Dividing the frequency of each species by the total frequencies of all species gave a slightly more accurate representation of dry weight composition than converting frequency to relative density or using actual density. The frequency addition procedure is much quicker than either procedure involving density.
\end{abstract}

One of the basic assumptions of the microhistological technique outlined by Sparks and Malechek (1968) is that a one to one relationship exists between relative density and percent dry weight of identifiable fragments ground to a uniform size through a 1-mm screen. Sparks and Malechek (1968) determined that in 11 different mixtures the "frequency conversion" method using the Fracker and Brischle (1944) table gave the same dry weight composition estimates as the more laborious "particle count"(density) method. The mathematical rationale for converting frequency to density in microhistological studies is discussed by Johnson (1982). Sparks and Malechek reported that frequency observations from 100 microscope fields examined at $125 \times$ gave an accurate evaluation of plant fragments on microscope slides. However, they did state that exceptions may exist. Other studies conducted by Vavra and Holechek (1980), Johnson and Pearson (1981), Holechek and Gross (1982), and Holechek et al. (1982) have confirmed that the relationship reported by Sparks and Malechek (1968) is generally true with a few exceptions. The objective of this study was to evaluate the accuracy of 3 procedures for calculating the percent by weight of hand-compounded mixtures when microhistological analysis was used.

\section{Methods}

In the summer of 198010 known plant mixtures were compounded using species from semidesert range in southcentral New Mexico (Table 1). Species used in the diets included tobosa grass (Hilaria mutica), mesa dropseed (Sporobolus flexuosa), black grama (Bouteloua eriopoda), blue grama (Bouteloua gracilis), green sprangletop (Leptochloa dubia), silver bluestem (Bothriochloa saccharoides), Russian thistle (Salsola kali), faint crown (Aphanostephus ramosissimus), leatherleaf croton (Croton corymbulosus), scarlet globemallow (Sphaeralcea coccinea), fourwing saltbush (Atriplex canescens), gray oak (Quercus grisea), and honey mesquite (Prosopis glandulosa). All plant material was dried in a forced air oven and ground through a micro-Wiley mill with a l-mm screen. Five slides were prepared from each mixture by soaking diet material in sodium hydroxide as discussed by Holechek (1982) and mounted as discussed by Sparks and Malechek (1968). At least 20 frequency observations were recorded per slide to insure high repeatability between slides as discussed by

\footnotetext{
Authors are assistant professor and graduate research assistant, Department of Animal and Range Sciences, New Mexico State University, Las Cruces 88003 .

This report is Journal Article 824, Agricultural Experiment Station, New Mexico State University, Las Cruces 88003 .

Manuscript received February 13, 1981.
}

Holechek and Vavra (1981). Twenty microscope fields were read at $125 \times$ for each slide by 3 experienced observers trained by Holechek and Gross (1982) procedures. All identifiable particle fragments in each field were recorded. Hairs and trichomes were disregarded. All unidentifiable fragments in each field were fully observed by moving the microscope slide to allow complete examination. Because our objective was to identify the calculation procedure giving the most accurate results, observers did not use correction factors to prevent over or under evaluation of certain species as recommended by Dearden et al. (1975), Vavra and Holechek (1981), and Holechek and Gross (1982).

Three procedures were used for estimating dry weight composition of each mixture. In the first procedure the number of identifiable fragments of each species in all fields was divided by the total number of identifiable fragments of all species in all fields. This procedure is equivalent to the "particle count" method of Sparks and Malechek (1968). Procedure two involved the conversion of frequency to density with the Fracker and Brischle (1944) table as discussed by Sparks and Malechek (1968). Procedure three involved dividing the frequency of each species by the total number of frequencies for all species.

The estimated percentage of each species in each mixture was compared to the actual percentage using the standard $t$-test and the 3 observers as replications. The percent similarity between estimated and actual dry weight composition was calculated with Kulcyznski's formula (Oosting 1956).

\section{Results and Discussion}

The frequency addition procedure gave slightly better overall accuracy than the actual density or frequency conversion procedures when similarity indices for the 10 mixtures were averaged (Table 1). Estimated and actual species values differed significantly $(P<.05)$ in $38 \%, 38 \%$ and $31 \%$ of the cases for the

Table 1. Percent similarity between actual and estimated percent by weight mixture composition when actual density, frequency conversion, and frequency addition calculation procedures are used.

\begin{tabular}{|c|c|c|c|}
\hline Mixture $^{t}$ & $\begin{array}{l}\text { Actual } \\
\text { density }\end{array}$ & $\begin{array}{c}\text { Frequency } \\
\text { conversion } \\
\text { (Fracker and } \\
\text { Brischle } \\
\text { Table) }\end{array}$ & $\begin{array}{c}\text { Frequency } \\
\text { addition }\end{array}$ \\
\hline 1 & 95 & 95 & 95 \\
\hline 2 & 95 & 95 & 97 \\
\hline 3 & 76 & 80 & 87 \\
\hline 4 & 97 & 94 & 95 \\
\hline 5 & 92 & 90 & 93 \\
\hline 6 & 75 & 82 & 76 \\
\hline 7 & 87 & 90 & 93 \\
\hline 8 & 94 & 97 & 97 \\
\hline 9 & 83 & 70 & 88 \\
\hline 10 & 93 & 94 & 94 \\
\hline $\mathbf{X}$ & 89 & 89 & 92 \\
\hline
\end{tabular}


Table 2. The percent by weight composition of $\mathbf{1 0}$ hand-compounded mixtures when 3 different methods are used for calculation.

\begin{tabular}{|c|c|c|c|c|c|c|c|}
\hline & $\begin{array}{l}\text { Total number } \\
\text { of identifiable } \\
\text { fragments in } \\
100 \text { fields }\end{array}$ & $\begin{array}{l}\text { Percent } \\
\text { frequency }\end{array}$ & $\begin{array}{c}\text { Frequency } \\
\text { converted } \\
\text { to density } \\
\text { (Fracker } \\
\text { and Brischle } \\
\text { table) }\end{array}$ & $\begin{array}{c}\% \text { dry } \\
\text { weight } \\
\text { using } \\
\text { actual } \\
\text { density }\end{array}$ & $\begin{array}{l}\% \text { dry weight } \\
\text { using Fracker } \\
\& \text { Brischle } \\
\text { frequency to } \\
\text { density } \\
\text { conversion }\end{array}$ & $\begin{array}{l}\text { \% dry } \\
\text { weight } \\
\text { using } \\
\text { frequency }\end{array}$ & $\begin{array}{c}\text { Actual } \% \\
\text { dry } \\
\text { weight }\end{array}$ \\
\hline \multicolumn{8}{|l|}{ Mixture 1} \\
\hline Tobosa grass & 33 & 28 & 33 & 19 & 18 & 18 & 20 \\
\hline Mesa dropseed & 39 & 32 & 38 & 22 & 21 & 21 & 20 \\
\hline Russian thistle & 36 & 31 & 37 & 21 & 21 & 21 & 20 \\
\hline Faint crown & 28 & 26 & 30 & 16 & 17 & 17 & 20 \\
\hline Fourwing saltbush & 38 & 34 & 41 & 22 & 23 & 23 & 20 \\
\hline Total & 174 & 151 & 179 & 100 & 100 & 100 & 100 \\
\hline \multicolumn{8}{|l|}{ Mixture 2} \\
\hline Mesa dropseed & 144 & 74 & 135 & $80 * 1$ & $80^{*}$ & 72 & 75 \\
\hline Russian thistle & 35 & 29 & 34 & $20^{*}$ & $20^{*}$ & 28 & 25 \\
\hline Total & 179 & 103 & 169 & 100 & 100 & 100 & 100 \\
\hline \multicolumn{8}{|l|}{ Mixture 3} \\
\hline Black grama & 26 & 22 & 25 & $14^{*}$ & $16^{*}$ & $19 *$ & 30 \\
\hline Leatherleaf croton & 127 & 65 & 105 & $69^{*}$ & $66^{*}$ & $58^{*}$ & 45 \\
\hline Honey mesquite & 31 & 26 & 30 & $17^{*}$ & $19^{*}$ & 23 & 25 \\
\hline Total & 184 & 113 & 160 & 100 & 100 & 100 & 100 \\
\hline \multicolumn{8}{|l|}{ Mixture 4} \\
\hline Green sprangletop & 34 & 28 & 33 & 20 & 19 & 22 & 20 \\
\hline Scarlet globemallow & 75 & 55 & 80 & 43 & $46^{*}$ & 43 & 40 \\
\hline Honey mesquite & 65 & 45 & 60 & 37 & $35^{*}$ & $35^{*}$ & 40 \\
\hline Total & 174 & 128 & 173 & 100 & 100 & 100 & 100 \\
\hline \multicolumn{8}{|l|}{ Mixture 5} \\
\hline Tobosa grass & 19 & 19 & 21 & 10 & 10 & 10 & 11.1 \\
\hline Blue grama & 22 & 20 & 22 & 11 & 11 & 11 & 11.1 \\
\hline Silver bluestem & 21 & 20 & 22 & 11 & 11 & 11 & 11.1 \\
\hline Leatherleaf croton & 37 & 33 & 40 & $19^{*}$ & $20^{*}$ & $18^{*}$ & 11.1 \\
\hline Faint crown & 16 & 16 & 17 & $8^{*}$ & 8 & $9 *$ & 11.1 \\
\hline Russian thistle & 18 & 17 & 19 & 9 & 9 & 9 & 11.1 \\
\hline Gray oak & 21 & 19 & 21 & 11 & 10 & 11 & 11.1 \\
\hline Fourwing saltbush & 20 & 18 & 20 & 10 & 10 & 10 & 11.1 \\
\hline Mountain mahogany & 19 & 19 & 21 & 11 & 10 & 11 & 11.1 \\
\hline Total & 193 & 181 & 203 & 100 & 99 & 100 & 99.9 \\
\hline \multicolumn{8}{|l|}{ Mixture 6} \\
\hline Black grama & 96 & 80 & 129 & $55^{*}$ & $62 *$ & $56^{*}$ & 80 \\
\hline Scarlet globemallow & 29 & 21 & 24 & $16^{*}$ & 11 & $14^{*}$ & 10 \\
\hline Leatherleaf croton & 51 & 43 & 56 & $29 *$ & $27^{*}$ & $30^{*}$ & 10 \\
\hline Total & 176 & 144 & 209 & 100 & 100 & 100 & 100 \\
\hline \multicolumn{8}{|l|}{ Mixture 7} \\
\hline Blue grama & 53 & 45 & 60 & $26^{*}$ & $28^{*}$ & $29 *$ & 33.3 \\
\hline Tobosa grass & 56 & 47 & 63 & $28 *$ & $29 *$ & 31 & 33.3 \\
\hline Leatherieaf croton & 94 & 61 & 94 & $46^{*}$ & $43 *$ & $40^{*}$ & 33.3 \\
\hline Total & 203 & 153 & 217 & 100 & 100 & 100 & 99.9 \\
\hline \multicolumn{8}{|l|}{ Mixture 8} \\
\hline Blue grama & 44 & 39 & 50 & 24 & 25 & 25 & 25 \\
\hline Silver bluestem & 41 & 37 & 46 & 22 & 23 & 23 & 25 \\
\hline Mesa dropseed & 42 & 38 & 48 & 23 & 24 & 24 & 25 \\
\hline Scarlet globemallow & 56 & 43 & 56 & $31^{*}$ & 28 & 27 & 25 \\
\hline Total & 183 & 159 & 200 & 100 & 100 & 99 & 100 \\
\hline \multicolumn{8}{|l|}{ Mixture 9} \\
\hline Green sprangletop & 31 & 25 & 29 & $15^{*}$ & $12 *$ & $18^{*}$ & 25 \\
\hline Leatherleaf croton & 136 & 86 & 196 & $67 *$ & $79^{*}$ & $62^{*}$ & 50 \\
\hline Fourwing saltbush & 35 & 27 & 32 & $18^{*}$ & $8 *$ & $20^{*}$ & 25 \\
\hline Total & 202 & 138 & 247 & 100 & 99 & 100 & 100 \\
\hline
\end{tabular}




\begin{tabular}{|c|c|c|c|c|c|c|c|}
\hline & $\begin{array}{c}\text { Total number } \\
\text { of identifiable } \\
\text { fragments in } \\
100 \text { fields }\end{array}$ & $\begin{array}{l}\text { Percent } \\
\text { frequency }\end{array}$ & $\begin{array}{c}\text { Frequency } \\
\text { converted } \\
\text { to density } \\
\text { (Fracker } \\
\text { and Brischle } \\
\text { table) }\end{array}$ & $\begin{array}{c}\% \text { dry } \\
\text { weight } \\
\text { using } \\
\text { actual } \\
\text { density }\end{array}$ & $\begin{array}{l}\text { \% dry weight } \\
\text { using Fracker } \\
\text { \& Brischle } \\
\text { frequency to } \\
\text { density } \\
\text { conversion }\end{array}$ & $\begin{array}{c}\text { \% dry } \\
\text { weight } \\
\text { using } \\
\text { frequency }\end{array}$ & $\begin{array}{c}\text { Actual } \% \\
\text { dry } \\
\text { weight }\end{array}$ \\
\hline \multicolumn{8}{|l|}{ Mixture 10} \\
\hline Tobosa grass & 31 & 29 & 34 & 14 & 14 & 14 & 15.0 \\
\hline Black grass & 26 & 26 & 30 & 12 & 12 & 12 & 12.5 \\
\hline Silver bluestem & 24 & 23 & 26 & 11 & 11 & 11 & 12.5 \\
\hline Mesa dropseed & 38 & 38 & 48 & $17^{*}$ & 20 & 18 & 20.0 \\
\hline Green sprangletop & 11 & 10 & 10 & 5 & 4 & 5 & 5.0 \\
\hline Russian thistle & 13 & 13 & 14 & 6 & 6 & 6 & 5.0 \\
\hline Faint crown & 8 & 8 & 8 & 4 & 3 & 4 & 5.0 \\
\hline Leatherleaf croton & 22 & 20 & 22 & $10^{*}$ & $9 *$ & $9 *$ & 5.0 \\
\hline Fourwing saltbush & 34 & 32 & 38 & 16 & 16 & 15 & 15.0 \\
\hline Honey mesquite & 12 & 12 & 13 & 5 & 5 & 6 & 5.0 \\
\hline Total & 219 & 211 & 243 & 100 & 100 & 100 & 100.0 \\
\hline
\end{tabular}

1*Observed value differs significantly $(P<.05)$ from the actual value.

actual density, density conversion and frequency addition techniques, respectively (Table 2).

Most of the mixtures containing leatherleaf croton showed poor agreement between estimated and actual species values regardless of the diet calculation technique used (Table 1). This is explained by the fact that leatherleaf croton requires the use of a correction factor for accurate estimation because of excessive fragmentation.

The frequency addition procedure did not provide the most accurate evaluation of dry weight composition for all mixtures. Mixture six (Table 2) demonstrates that when an overestimated species is a minor mixture component, the density conversion procedure actually gives the most accurate results. This is because the Fracker and Brischle (1944) conversion increases the density of a species with a high frequency to a greater extent than for a species with a lower frequency. Conversely mixtures three and nine demonstrate how the Fracker and Brischle (1944) conversion can severely reduce accuracy when the overestimated species is a major mixture component. The higher accuracy of the frequency conversion procedure is explained by the fact it reduces overestimation of species with easily identifiable fragments and/or that fragment excessively during sample preparation. This source of error is magnified by the actual density procedure. The density conversion procedure either magnifies or reduces this source of error depending on whether the frequency of the overestimated species is low or high in relation to other species in the mixture.

Our results indicate that the frequency addition procedure gives equal or better accuracy than the frequency to density conversion or the actual density procedure for calculating relative percent dry weight composition. It has the additional advantage of being much quicker and more simple.

\section{Literature Cited}

Dearden, B.L., R.E. Pegau, and R.M. Hansen. 1975. Precision of microhistological estimates of ruminant food habits. J. Wildl. Manage. 39:402-407.

Fracker, S.B., and J.A. Brischle. 1944. Measuring the local distribution of Ribes. Ecology 25:283-303.

Holechek, J.L., and B.D. Gross. 1982. Training needed for quantifying simulated diets from fragmented range plants. J. Range Manage. 35:644-647.

Holechek, J.L., and M. Vavra. 1981. The effect of slide and frequency observation numbers on the precision of microhistological analysis. $J$. Range Manage. 34:337-338

Holechek, J.L., B.D. Gross, S.M. Dabo, and T. Stephenson. 1982. Effects of sample preparation, growth stage and observer on microhistological analysis. J. Wildl. Manage. 46:502-505.

Holechek, J.L. 1982. Sample preparation techniques for microhistological analysis. J. Range Manage. 35:267-269.

Johnson, M.K. 1982. Frequency sampling for microscopic analysis of botanical compositions. J. Range Manage. 35:541-542.

Johnson, M.K., and A.A. Pearson. 1981. Esophageal, fecal and exclosure estimates of cattle diets on a longleaf pine-bluestem. J. Range Manage. 34:232-235.

Oosting, H.J. 1956. The Study of Plant Communities. W.H. Freeman and Company, San Francisco. 440 p.

Sparks, Donnic R., and John C. Malechek. 1968. Estimating percentage dry weight in diets using a microscope technique. J. Range Manage. 21:264-265.

Vavra, M., and J.L. Holechek. 1980. Factors influencing microhistological analysis of herbivore diets. J. Range Manage. 33:371-374. 